\title{
Heading South But Looking North: Globalization and Law Reform In Latin America ${ }^{1}$
}

Joseph R. Thome

Throughout Latin America, law reform is in the air. After decades of neglect, its legal systems are experiencing substantial if not drastic processes of reform and transformation. The administration of justice in particular has been singled out as inefficient, if not corrupt, inaccessible to most, unable or unwilling to respond to human rights abuses, and largely irrelevant to the needs of modern economies.

These reform processes respond to global and domestic actors and pressures. On the surface, both share the goal of helping to cement good governance, including the rule of law, throughout Latin America. This apparent goal consensus, however, can be broken down into two different orientations which reveal not only agreement but also overlapping and sometimes conflicting goals:

a) Market Orientation: an appropriate legal environment including uniform, predictable and enforceable rules securing property and contract rights is viewed as crucial for modernizing the Latin American economies and incorporating them into a global economy characterized by unrestricted trade and free-market efficiency;

b) Democratic Orientation: an effective rule of law is also deemed vital for consolidating democratic institutions; making legal systems more transparent, responsive to social needs and accessible to the

1 Paper presented at Law \& Society 2000 Annual Meeting Miami Beach, Florida, May 26-29, 2000 A version of this paper will be published in Fall 2000, University of Wisconsin Law Review. 
disadvantaged sectors of society; and preventing human rights violations while simultaneously becoming more efficient in preventing and sanctioning criminal activity.

Furthermore, both domestic and global actors also seem to agree that reaching these somewhat contradictory goals would require a more independent, effective and accessible administration of justice, including broad powers of judicial review and new civil and criminal trial institutions and processes throughout the complex set of institutions that make up the administration of justice sector. Indeed, in recent years several Latin American nations have incorporated reform proposals into national legal frameworks through constitutional amendments or new legislation.

But this apparent harmony of interests, goals and means may mask conceptual vagueness as well as tensions and contradictions between global and national goals and policies, and, indeed, even among themselves. Establishing market-friendly legal frameworks can clash with the democratic goal of facilitating access to the courts to historically excluded interests, such as non-unionized workers, women, and the poor in general. Similarly, a majority population facing rising criminality may use democratic means to push for stricter and more efficient law enforcement, even at the expense of the human rights of those suspected of criminal activity. Finally, potential distortions of programs or implementation problems also are sometimes overlooked. Correa 1993:97), for instance, has pointed out that dominant elements of the judiciary may outwardly support legal reform but, perceiving it as threatening to their corporative interests or status within the administration of justice, may operate behind the scenes to undermine or control the process.

This hard to unravel socio-legal tapestry calls for deep studies of reform goals, of social, political and national and global contexts in which the reform processes are inserted, and of the various conflicts, tensions and sometimes unforeseen consequences these reforms mask or have produced. Fortunately, these studies are beginning to emerge, though empirical and evaluative studies still are hard to come by. While this paper does not pretend to be the product of empirical and field country studies, it will try to bring to light some of the values and premises underlying both global and domestic reform policies, and 
examine other sometimes unstated but nevertheless relevant factors which affect both the articulation and implementation of reform goals, including the links between global and domestic actors and forces on these processes of legal reform.

\section{The Global Perspective of Legal Reform in Latin America}

Because of perceived links between the rule of law, democracy and development, legal reform has become a focal point in the world of international assistance. The world, of course, has changed; the end of the Cold War and the collapse of the Soviet Union and the emergence of Western hegemony no doubt played a key role in the emergence of this emphasis on democratic institutions and market-oriented development. On the one hand, international human rights have become part of national political agendas, pointing to the need for legal reform to meet its principles. On the other hand, the "Washington Consensus" has become [...] the dominant paradigm in development thinking [...]» As such, it «[...] promotes markets as allocative institutions, favors privatization and promotes closer linkages to the global economy». Meeting this goal requires an appropriate legal framework, making legal reform essential (Trubek,1996:224-225).

To a large extent this global process has provided the opportunity to focus on the economic failures, corruption, human rights abuses and similar ills plaguing most of the developing nations, to a large degree blamed on the prevalence of undemocratic or patrimonial regimes and institutions. As Donelly puts it (1999: 610): «democracy, although not strictly necessary for development [...] may restrict predatory misrule that undermines development». True enough, the systematic denial of civil and political rights does not necessarily hinder economic development, as shown by the experience of Europe and the United States in the 19th century, and South Korea, Taiwan, Brazil and Chile in recent decades, bringing into question the relevance of a democratic legal environment for the development of free-market economies. Nevertheless, while the power of human rights and of such concepts as democracy and rule of law should not be overemphasized, the Vienna declaration of 1993 constitutes a strong endorsement of the universality of such rights and most states today appeal to human rights, democracy 
and development as way of establishing national and international legitimacy. Moreover, «[...] civil and political rights, by providing accountability and transparency, can help to channel economic growth into national development rather than private enrichment" (Donelly, 1999:610-611.). This position in turn has led to a perceived need for a liberal constitutional order with political pluralism, fair elections, a strong and independent judiciary and an efficient and responsible administration. Constitutionalism, as it were, has "come in from the cold» (Ghai, 1993:52-53.)

Liberal constitutionalism is indeed relevant for Latin America, particularly in view of current transitions from authoritarian to democratic regimes and from state-intervened economies to free markets and insertion in global economies. The components of this transition include the separation of state and civil society, the rule of law, and the limitation of the scope of governmental power. Liberal constitutionalism and the rule of law embody certain basic values emphasizing individual civil, political and property rights, underpinned by the concept of the equality of all citizens under the law. This is a powerful ideology which can be, and some would argue, has been, used to legitimate the dominance of elites and Western regimes throughout the world while at the same time limiting the arbitrary power of the state. (Ghai, 1993:53-56.)

The debate about legal reform thus takes us to the role of the State and law in the current globalization process. The State now must contend with different forces; nationally, it must deal with all the demands and constrictions of the internal political process, and internationally, it must respond to global economic and political processes and pressures. This scenario introduces complexities into classical notions of the State and necessarily impacts on the affected legal spheres.

In Latin America, the received concept of legal science became ingrained as a foundational principle of the new legal systems within decades of their independence in the early 19th century. As befits a "science», law was perceived as rational and non-political. Responding to similar drives to mold national states out of diverse factions and ethnicities, the emerging Latin American nations also received the concept of 'legal positivism' from Europe; the State was to be the sole source of law and all other norms given a subsidiary status as social, 
religious, or, in the case of the indigenous peoples, primitive norms. Official legal statism, however, never fully established a true monopoly over legal relations. Aside from national law, both local and supranational law continued to play important roles in regulating individual, social and state behavior. Indeed, these legal pluralities have become more prominent and recognized in the current globalization process.

Latin American countries also embraced the original French doctrine of separation of powers under which courts were to play a relatively minor role in the legal process. For one thing, they were not to make law, only to interpret and apply it. Under this doctrine, there are, strictly speaking, no binding precedents, nor erga omnes judicial review of the constitutionality of statutes, as contrasted to the constitutionality of its application to a specific, individual case. While courts usually can review the legality of administrative actions, this review is usually limited to the specific and particular application of executive power, and has no broad ranging application to the law or regulation under consideration. Civil Law countries have been moving toward a US type of judicial review, but this is a recent development and has yet to become the norm throughout Latin America.

Needless to say, the end of the millennium brought with it new challenges to the paradigms of modernity reflected in such notions of the State and law. For Santos legal systems are hybrid, as they reflect multiple modernities and traditions. In Latin America, for instance, the pre-modern, the modern and the post-modern co-exist even among the same people. Though Latin America always was active in world markets, the more recent and complete integration into Northdominated global economies make legal hybridization even more evident. Following Santos, we could say that the process of globalization consists of two principal modes:

"Globalized localism", describes the process by which by which a local condition succeeds in extending its reach over the globe, with the capacity of designating any other condition as «local». Examples can go from the proliferation of fast food outlets to the management strategies of first world corporations. Indeed, some would argue that the current programs of legal reform to a large degree reflect this process, as US or European legal institutions become the basis for such reforms. "Localized globalism», on the other hand, refers to the impact of the received institution on the local context, and conversely, how this local 
context, such as a different legal and political culture, in turn affects the received institution or process. A legal reform with very similar imported components produces results in, say, Costa Rica that are different from those in Peru. In any case, the resulting institutions will not match those from the "exporting" nation.

The dynamic relationship between these two modes substantially affects the shape and content of current legal reform programs This is a "frontier zone", charged with ambiguities, where different contexts and realities will produce different results (Sassen, 1999.) As examined in more detail below, for instance, the World Bank's law reform policies and programs have become more socially sensitive and inclusive, shifting from a narrow market orientation focus to a wider lens that includes the indigenous, the poor, and other marginalized sectors of society. In my view, this evolution probably reflects a "localizing" effect; as the Washington elaborated Bank policies and programs moved South, new and often conflicting voices were heard and the Bank began to readjust its agenda. The Bank, however, has yet to resolve inherent contradictions or conflicts within its new broader agenda.

\section{The World Bank: Law Reform Policies and Implementation Strategies}

Legal reform, particularly as regards the role of the judiciary in social and economic development, has become an essential ingredient among multilateral agency policies and programs. The World Bank is a major player in promoting legal reform. According to the General Counsel, Legal Department of the World Bank, for instance,

The World Bank's activities to strengthen institutions and policies affecting legal and judicial systems have grown markedly in the past few years. The Bank has prepared 10 free-standing judicial reform operations that have been approved by the Board, and another 14 are currently under preparation. In addition, 15 other projects address legal and judicial issues from a broad systemic perspective, such as reforms of the law-making process and the judiciary and alternative dispute resolution mechanisms. Beyond that, there are some 350 operations in 87 countries that finance specific legal reform activities (Rigo Sureda, 1999: 20.).

Initially, the Bank's focus seemed narrowly fixed on "rethinking the role of the state and the current mode of development [...]", in order 
to place «[...] a greater reliance on markets and the private sector, with the state acting as an important facilitator and regulator of private sector activity and development». Achieving this end would require a major reform effort, including "[...] the building of a legal framework for development, and enforcement of the rule of law» (Aiyer, in Rowat et al.,1995:vii.) The judiciary, as an essential component of this process, would have to foster an enabling legal and judicial environment conducive to trade, financing and investment. In the view of the Bank, however, the Latin American judiciary had become an impediment to these ambitious goals due to its inefficiency, as characterized by lengthy case delays, limited access to justice, a lack of transparency and predictability, and poor public confidence in the system. Thus, the goal of sustainable economic development was perceived at risk because of the lack of enforcement of the rule of law. Dakolias (1995:167169), a Bank official deeply involved in its law reform efforts, also viewed judicial reform as a key component for promoting economic development, inasmuch as autonomous and dependable judicial systems are a basic condition for membership in the global economy, entailing the responsibility of bringing about harmonization of law and assuring foreign traders and investors that the law will be applied in accordance with international or regional standards.

As the Bank became more aware of the complexity of the «judicial sector", its role in society, and of the problems involved in attempting to push for reforms in societies with conflicting interests, groups, and institutions, the Bank's articulation of policies and strategies for legal reform have become more nuanced and contextualized. As of 1995, for instance, it recognized that implementing reforms would require a gradual or incremental process feasible within the political and economic capacity of each nation. Given political limitations and pragmatic considerations, the Bank found coalition building necessary. Moreover, the Bank was seemingly aware that the initial push for reform process should come from within the affected country; with grass root involvement, town meetings and other local participation suggested as mechanisms for raising the necessary broad base of support (Dakolias, 1995: 225-231).

However, a 1996 study by The Lawyers Committee of Human Rights (Lawyers Committee) and the Venezuelan Program for Human Rights Education (PROVEA) of the World Bank-financed Venezuela Judicial 
Infrastructure Project documented wide gaps between the Bank's articulated policies and its actions. Launched in 1992, this judicial reform project was supported by a $\$ 30$ million Bank loan and its technical assistance; indeed, it was «[...] "marketed" as the Bank's flagship involvement in this area, setting the stage for a number of other judicial reform projects in Latin America and elsewhere" (Lawyers Committee, 1996:1).

The Report cites the Bank's recognition that reform could not be imposed from the outside. Moreover, The Bank also emphasized the need for prior diagnostic studies and set out several essential criteria for program implementation. But as of 1996, "“[...] the Bank's record to date in each of these areas has, unfortunately, been mixed at best" (Lawyers Committee, 1996:3.) The Project was not part of a comprehensive reform strategy; there was no broad government commitment to reform; reform strategies failed to address crucial structural impediments to judicial independence; access to justice concerns were not addressed; and, there was no broad based participation in the design and development of the Project. Consequently, actual accomplishments were limited in scope (Lawyers Committee, 1996:6-10.)

True enough, the Bank's policy articulations now reflect a broader understanding of the diverse goals, principles, and interests affected by law reform programs. For instance, the Bank has linked development to the protection of human rights, which in turn depends on a strong, accessible, and independent judiciary. At the same time, the Bank has asserted that «accessible and efficient courts are essential to the attainment of sustainable and broad-based economic growth. In any society striving to achieve economic growth, the government must guarantee that contracts are honored and property rights are respected, and that domestic and foreign investors trust it to ensure that their investments enjoy legal protection. with access" (Press Backgrounders, 1999. ) The Bank also has stressed that human rights in developing countries are best safeguarded by improving the conditions of indigenous communities. Programs to fulfill this goal include improving the quality of education, health and sanitation, land reform and judicial reform.

James D. Wolfensohn, the president of the World Bank, is well aware that market economies rewards some more than others. Referring to developing countries, he recognizes that populations «remain split 
along a fault line that separates the lives and aspirations of the rich and poor" (N.Y. Times, 2000:10.) Moreover, he regards legal systems as crucial, in that without the protection of human and property rights and a comprehensive framework of laws, no equitable development is possible. A government must ensure that it has effective systems of property, contract, labor, bankruptcy, commercial codes, personal rights laws, and other elements of a comprehensive legal system that is effectively, impartially, and cleanly administered by a well-functioning, impartial, and honest judicial and legal system (Cited by Rigo Sureda, 1999: 19.).

Still, the Bank's policy articulation and program emphasis reflect contradictory goals, apparently not acknowledged by the Bank, and its positions seemingly continue to largely reflect a "Globalized localism" orientation.

This is not to say that the Bank's policy and strategy positions are irrational and indefensible. But the inherent contradictions in the Bank's policies and program raise important questions that can vitally affect the implementation of its programs. The diversity of interests and even conflicts between different sectors of society must be recognized and addressed. A prime example is the problem of rising criminality and the social demand for more effective police, which clearly engenders tension between the demands for «law and order» and the internationally recognized human rights of due process and humane treatment of those accused of criminal activity. Similarly, Guatemalan landless peasants will read the Bank's call for land reform in a manner that will inevitably clash with the landowner's interpretation of the World Bank's strongly held position that contract and property rights are essential for development. Conflicts between indigenous peoples asserting their ancestral land rights and the interests of local or foreign investors, government contract in hand, have become commonplace, sometimes leading to the abandonment of projects. If eventually a type of judicial or other "official" intervention is required, how should these conflicts be resolved? Through "customary" indigenous law and institutions, or in accordance to the newly reformed and "efficient" national legal systems that the Bank has been promoting?

To be sure, as noted, the Bank appears to have learned from its experience and to have broadened its policy and programmatic agenda. Nonetheless, the judiciary remains the cornerstone of the Bank's legal 
reform programs. But is such an emphasis well-placed? Even a superficial overview of Latin America's legal history reveals a judiciary with little social relevance, usually subservient to the executive on most important political issues as long as its corporative prerogatives were preserved, and mostly engaged in routine activity. Indeed, the image of the judge largely remains that of a faceless bureaucrat adverse to innovation. Despite some important exceptions such as Costa Rica and some clearly dedicated and innovative judges, most Latin American judiciaries have yet to show a genuine commitment to the full panoply of democratic institutions and rights.

Indeed, we could view with skepticism the relevancy of adopting "modern" and expensive judicial processes in at least those countries where the "rule of law" has seldom been legitimate and many people cannot even read. Judicial review powers and independence for a nation's Supreme Court together with sophisticated computerized systems, for example, may be irrelevant for most people, whose interaction with "law» is generally limited to low level bureaucrats and the police. In this context, will an improved official administration of justice necessarily lead to a more accessible judiciary for everyone, or simply to a more efficient mechanism to protect the interests of the advantaged sectors of society?

None of the above is to deny that the judiciary and legal processes in Latin America do not need substantial improvement. Their inadequacies and problems have ben well documented. But there are clear risks in using models from the North to fix the legal «insufficiencies» without due regard to the particular needs and contexts of the Southern «receiving" societies.

\section{The National Perspective, or Localizing the Global}

Global policies and programs, even if agreed upon, often are mediated and given new meaning or even diverted by national reality. Moreover, the dynamic relationship between global and local forces also affects the exporting agency, which may begin to question some of its initial premises, policies and operational strategies. A case in point is the evolution of the World Bank's positions regarding the law reform programs it has promoted in Latin America. 
Understanding the local context thus is necessary to shift from an ethnocentric "globalizing" perspective to a «localizing» one; this exercise should provide different - if at times overlapping- questions and issues that are more rooted in the particular social context. Throughout Latin America, for instance, "Rule of Law» principles and processes are proclaimed in official documents and reiterated in substantive legal norms. But in practice they are often absent from or unevenly distributed, producing a gap between the ideal "law in the books" and the operative "law in action", even within Latin America's more "developed" societies. This situation predates the authoritarian regimes of the 70s and $80 \mathrm{~s}$ and, unfortunately, continue in some degree to plague both re-democratized societies (eg., Argentina, Brazil, Chile, and El Salvador) and others that arguably did not suffer from authoritarian regimes (eg., Colombia, Mexico and Venezuela). Indeed, according to Pinheiro, «Since the return of democratic rule to many countries in Latin America, relations between governments and members of society have been characterized by illegal and arbitrary use of power», with many authoritarian practices and violations of human rights unaffected by political changes or elections (1999:1.).

This situation is largely due to the socio-political context, which has a direct impact on the norms, processes, institutional structures and culture of a given legal system. In most of Latin America, for instance, judicial systems traditionally were politicized, usually intertwined with or dependent on the executive, even as they retained substantial corporative autonomy. This patrimonial trait, a part of the region's colonial heritage, became even more evident in the 1920s and 1930 s when in response to pressure from below and the economic crises of the times, Latin American societies embarked on nationalist, import substitution development programs conducted by an interventionist regulatory and welfare State dominated by the Executive branch.. Since the public sector was to prevail over market forces, the Executive assumed a key role in resolving conflicts among various key economic sectors and enterprises, where political and ideological considerations were often deemed more important than economic efficiency or legal prescriptions. In the process, the role of the judiciary became relatively minimal, as important conflicts were aired and resolved in other arenas -administrative agencies, semi-autonomous state enterprises or the offices of a Minister or the President himself (Co- 
rrea, 1993: 94; Perez Perdomo,1993:132-135.) The courts were relegated to such functions as deciding debt collection cases, or to processing common criminals (white collar crime was largely ignored.)

This process had very negative consequences for an already weak Administration of Justice. Judges came to have little social relevance and mostly engaged in routine activity; the image of the judge became that of a bureaucrat adverse to innovation. The State for its part invested little in the administration of justice, which had to make do with obsolete technology, poor organization, and poorly paid and trained judges. Inefficiency, influence peddling and even corruption became common place throughout court houses of Latin America.

At the normative level, codes of civil and criminal procedure dating from the mid-nineteenth century and other dated legislation still burden the administration of justice in most of Latin America with a documentbased time consuming and expensive process. In Uruguay, for instance, the recently repealed code of civil procedure dated from 1879 , itself a copy of the Spanish Code of 1850 which contained many medieval elements (Marabotto,1993.) In addition, institutional/structural problems still plague the administration of justice throughout Latin America. Overcrowded dockets resulting from an insufficient number of poorly paid judges to handle case loads and the lack of adequate resources, in conjunction with civil and criminal procedures dominated by documentary, non-oral processes handled in chambers, encourages the resolution of cases by non-judicial staff, such as actuarios, or secretarios (Correa, 1993:8). Not rarely, a judge will barely skim over a case dossier produced by his law clerk and sign the findings with little or no analysis of her own. This is particularly serious in criminal prosecutions, raising issues of due process.

In most countries of Latin America, the judiciary is a public civil service career which nevertheless has been traditionally organized as a closed system. While externally subject to varying degrees of political control by the Executive, Supreme Courts generally exercise iron-hand control over internal court administration, including entry level selection and promotion of lower court judges. Once a member of the judiciary, a young judge is assigned to a lower trial court in one of the provinces, gradually moving up the career ladder into higher and better paid judicial positions and more amenable living conditions. If he perseveres and does not get into conflicts with the higher appellate courts and the 
Supreme Court, he might eventually be named to an Appellate Court or even to the Supreme Court. This system perpetuates a patronage system which rewards obeisance and good connections. But some progress is evident. A product of legal reform programs, new judicial schools in Chile, Uruguay and other countries appear to be eroding the patronage system. Merit has become a relevant criteria for selection, with preference being given to candidates who have successfully completed the full course or special seminars at the new judicial schools (CEJU,1993.).

A combination of social, structural and cultural forces also have made it difficult to attain effective access to justice, particularly for the more disadvantaged sectors of society. In Chile, for instance, a 1993 survey (Correa and Barros,1993:73-89) indicated that only 32\% of those who had suffered some criminal act (by far their most common "legal problem") actually called or went to the police to complain, and of those, a full $57 \%$ in effect received no response whatsoever. In the end, out of every 100 victims of a criminal act, only 1.5 obtained a full criminal prosecution against a defendant. It is hardly surprising, then, that $71 \%$ of those who denounced a criminal act concluded that their recourse to justice had been a waste of time, and that a full $68 \%$ of those who suffered a criminal act never bothered even to complain to any authority. For them, at least, "justice" was unattainable. Civil litigation is not any more accessible. As in most countries, for instance, litigating in Argentina does not come cheap: aside from lawyer's fees, as of late 1993 parties filing civil or commercial complaints must deposit in escrow with the court $3 \%$ of the amount claimed, recoverable only if the plaintiff wins the case (Prado, 1993.)

Finally, the legal culture, that is, prevailing perceptions of what the legal system stands for together with actual practices and customs that have become ingrained in the profession, can vitally affect its accessibility and effectiveness. Most Latin Americans have very negative opinions towards the legal processes in general and the administration of justice in particular. In Argentina, for example, 61\% of the sample of a 1992 Gallup poll pointed to an inefficient judicial system as the most important cause of corruption (cited in Moreno Ocampo,1993:199.) Similarly, a 1993 survey in lower income areas of the three major Chilean cities revealed that 83 percent of the sample had very negative perceptions of the administration of justice system in general, deeming 
it inefficient, discriminatory, arbitrary, slow, and corrupt (Correa and Barros, 1993: 23-26.).

Despite the paucity of empirical studies of the legal culture of the Latin American judiciary or other legal actors, legal and other scholars have long been concerned with the historical and social roots of the Latin American legal culture. Maier (1993:29-31), for instance, points to the cultural heritage from the colonial period. At the time of the conquest, the Spanish crown was engaged in a process of nation building and of centralizing power in an absolute monarchy. As it did with other institutions, the Spanish colonial regime imposed on its colonies a judicial system based on its own political model; namely, a centralized, hierarchical system with highly developed control mechanisms over the lower courts (Saez, 1998:1280.) The judiciary was structured as a bureaucratic organization, where power was delegated from the top down to inferior officials, and where every judge and other judicial personnel was a functionary at the service of the State, not of the individual. The judicial system thus was not really conceived as an institution to resolve the conflicts of the population at large, but rather as a component of the administration of State power; that is, as an instrument of social control.

This legal tradition was only partially affected by the process of independence in Latin America (Maier, 1993:32-35.) Rhetorical articulations of liberal ideology notwithstanding, independence and the replacement of absolute monarchism by Republican forms of government did not result in a new social order but rather in the replacement of an Iberian elite by its local or "criollo" counterpart, which did not particularly want to share political power with the impoverished masses. While the liberal reforms of 19th century Europe enlarged the sphere of individual rights, established the separation of powers and promoted greater citizen participation in the political process, their impact was attenuated in the vastly different social context of Latin America.

Despite recent reform efforts, the administration of justice in Latin America to a large extent continues to be based on a bureaucratic model; as such, it is hierarchically organized and retains a written process which facilitates the internal control of the proceedings (and the judicial functionaries), but strictly limits participation in the process by the affected parties. This is a model which still reflects the centralizing, 
patrimonial and non-participatory politico/legal culture inherited from Spanish colonial rule. As Moreno Ocampo puts it, "The law in this tradition is a means for the exercise of State power for the purpose of controlling its subjects" (1993:200.).

The legal profession largely continues to follow the «liberal» tradition of solo practice or, in the case of the larger and more «modern», internationally oriented firms, to be organized around families, akin to «legal dynasties» But the increasing sophistication and internationalization of these more modern legal practitioners, many with graduate degrees from the most prestigious law schools in the U.S., does not necessarily involve the absorption of human rights or democratic values. By and large, these "modern» lawyers are dedicated to private practice increasingly involving the structurin of business deals with domestic or foreign investors in accordance with internationallyaccepted criteria, but with little if any concern with issues touching on the role of law in society (Dezalay and Garth, 1998: 58-60.).

Though certainly not the only cause, to some extent the persistence of this legal culture can be linked to the traditional mode of legal education long dominant throughout Latin America. Notable exceptions apart, the five to six year formation and training received by law students lacks the broadening enrichment of critical debate but is rather anchored in traditional pedagogy based mostly on foreign legal sources, authoritarian in style, encyclopedist and with an emphasis on memorization. Given the "rationalist natural law" basis of the Codes, knowing their content is to know "the law". This thesis is inculcated throughout the long years of law school and reiterated in a legal scholarship with scant relations to reality, forming a dogmatic system of knowledge and truth few have been able to question or resist (Dezalay and Garth 1998: 32-33.) Legal scholarship and education to this day, despite growing critiques and some notable exceptions, continues largely unchanged.

The practical and instrumental aspects of the legal process are largely "learned" through work experience; as regards the more «modern" aspects of the law this opportunity is generally limited to those with the appropriate connections or who have managed to attend the more elite law schools. In any case, this aspect of the prevailing "legal culture» is not particularly conducive to a participatory democratic discourse or process, at a time when Latin American societies are engaged in serious efforts of «redemocratization» and economic modernization. To some 
degree, legal systems and institutions have lost relevance in face of the social and economic needs of the region (Faría, 1993:14,25.).

\section{Conclusions}

Perceptions of an interdependent and complex global economy/ democratization relationship with legal systems in general and its justice sectors in particular has led the World Bank, other global players, as well as national reformers, academics and economic and modernizing elites to demand changes in the administration of justice, leading to complex legal reform processes.

As noted, a primary rationale for the World Bank's active support for law reform projects in Latin America is the premise that secure and predictable legal environments are necessary for investment and market oriented development. But some careful students of Latin American legal systems question this premise, arguing instead that the certainty that investors seek has historically been more related to political rather than legal or judicial structures. To be sure, weak and inefficient judiciaries, crowded dockets and and other similar defficiencies are a reality throughout Latin America. But cases involving small debtors, minor offenses, common crime (as opposed to white-collar crime or corruption), among other problems, are the most frequent type of cases confronting the judicial systems in the region. The big players tend to solve their disputes in other settings, such as the top levels of administrative or executive agencies or international arbitration arenas (de la Barra, 1998.).

Even when, as in Argentina, effective innovations are adopted partially in response to foreign investors who want guarantees through legal institutions, these tend to be limited to private dispute resolution processes, such as mediation or arbritation, which function «outside but around the public institutions of the state" (Dezalay and Garth, 1998:95.)2 As a result, they conclude that the World Bank legal reform project in Argentina, initiated in 1992, «...has not resulted in any tangible results" (1998:89.) Given this context, perhaps the Bank and other multilateral agencies should reconsider their premise which considers the the judiciary as the primary institutional actor in producing the stability assumed to be necessary for market development. 2 
What of the presumed relationship between law and democratic institutions in Latin America? Latin American reformers, profoundly influenced by their harsh experiences under authoritarian regimes, have come to consider the an effective justice sector as a key factor for consolidating their as yet fragile redemocratization processes. As Correas notes (1986: 212-218), the only currently viable political and social project for Latin America is liberal democracy, which in turn implies a respect for the rule of law. Yet, these reform mongers would be the first to recognize that Latin American courts by and large do not carry a legacy as defenders of human rights or democratic institutions. As already argued, this is not solely due to lack of resources, inadequate technical training and other institutional deficiencies. Far more important are the legal and judicial cultures that have developed over centuries as a reflect of Latin America's political and social structures and processes. Saez insightfully recognizes that reform of the official judicial structure must go in tandem with relevant changes in informal institutions and organizational arrangements, as these largely have a controlling effect over the formal system (1998: 1319.) «Indeed, one of the basic questions confronting any reform effort is how much change can be produced within the justice sector, if extra-sectoral behavior remains relatively untouched" (Hammergren, 1998: 13.) The World Bank itself in a relatively recent policy statement suggests that judicial reform programs should "address the political, economic and legal causes at the root of an inefficient and inequitable judiciary,» as otherwise, «[...] there will be a minimal probability for success" (Lawyers Committee, 1996:6, quoting from an unspecified Bank source.

What, then, are the prospects for the current and proposed legal reforms in Latin America?

The financial resources available from various foreign donors have without a doubt influenced the process of reform. Nevertheless, several countries initiated reform projects and have made headway in their agenda prior to the arrival of the global agents or with minimal external or technical assistance. These include Brazil, Chile, Costa Rica, and Uruguay, with varying degrees of success (Hammergren, 1998: 23.) Indeed, critical re-evaluations and reformulation of their legal systems and important changes can be observed throughout the region. Traditional legal culture, For instance, is being challenged, and several law schools also have become active in legal reform movements, 
becoming more active in critical and policy oriented legal research and publications, and slowly introducing curriculum reform and clinics into their programs. Perhaps the most notable experiment, funded by the Ford Foundation, is an active public interest clinical program carried out among Law Schools in Argentina, Chile and Peru, which periodically meet to discuss their experiences and co-ordinate activities. (Gonzalez Morales, 1997.) Structural innovations include CEJU, the judicial school recently instituted in Uruguay, which has become the major source of candidates for the judiciary and the public prosecutor's office, in the process loosening the traditional hold of the Supreme Court over entry into the judicial career. Moreover, CEJU workshops are training sitting judges in ADR techniques as well as bringing them up to date on other legal developments and innovations. In Argentina, the Ministry of Justice has an well-organized program of mediation training and diffusion and has introduced it as an essential component in its legal aid clinics in four lower-income neighborhoods. Other countries also have inaugurated new judicial academies and are in the process of replacing the investigative (inquisitorial) magistrates with an independent public prosecutor's office, introducing oral hearings into their civil and criminal procedures and substantially improving its legal aid and public defender programs.

However, while oral trials and other innovative reforms can vastly improve the administration of justice, they require complementary structural improvements, including better trained judges and supportive, adequate physical space to enable judges to hold hearings with the presence of opposing parties, counsel and even interested public, computerization of judicial processes and computer links to essential legal data, and improvements in other public services whose timely collaboration is essential for an efficient administration of justice, such as the investigatory police, other departments who must issue official reports orstatistics, the public registries, and the like. Thus, even if the proposed reforms would lead to the desired goals, their implementation face difficult fiscal, political and technical hurdles that may well be beyond the capabilities of national entities and their external allies (Hammergren, 1998:25 et.seq.).

The rule of law and an accessible, efficient and fair administration of justice can be one of the essential building blocks for an effective democracy. But potentially adverse side effects from law reform projects 
cannot be ignored; a pure free-market approach, for instance, will inevitably lead to a concentration of resources in a privileged few. Thus, if the poor are to participate more evenly from economic growth, they must be provided with effective access to the allocation of goods and services, including justice. Similarly, if the long neglected but recently assertive indigenous peoples are to participate in the hoped for benefits of the reforms and become empowered as citizens, then neither global nor local actors can ignore the reality of "legal pluralism". Diverse and operational legal systems exist throughout Latin America; they are part of the legal universe and ignoring them is but social denial (Guevara and Thome, 1992.) Similarly, recognition and attention is due to the increasing and largely justified demands from provincial and municipal sectors for increased fiscal and political autonomy, calling for an end to the traditional system of centralized authority which prevails over most of Latin America.2 While the global economy is producing a push toward supra-national law and judicial review, indigenous and regional movements are at the same time "localizing" law and politics, initiating a process of redistribution of sovereignty where the state loses power in both directions (Merryman, 1985: 158).2

In discussing recent World Bank funded legal reform programs in Africa, McAuslan critically analyzes the Bank's premises and approaches to legal reform, questioning whether "[...] legal development $[. .$.$] can$ achieve good governance and can develop the market economy in both developing and transitional countries [...]" (1997:25.) Given this challenge, what should be the response of global agencies and other actors involved in legal reform? At the risk of being simplistic, I would suggest looking back before heading South, and once heading South, looking South. A logical starting point would be to carefully re-examine the Law and Development programs of the 1960s and 70s, also premised on the centrality of law for promoting development in the less developed countries. 2 To be sure, the world has changed since then, but nevertheless Law and Development's overall lack of success raises questions and provides lessons relevant to current global legal reform efforts. Indeed, one could ask, if 'law' didn't lead to 'development' then, why should it now?

To start, one need look no further than the 1974 seminal report by the Research Advisory Committee on Law and Development of International Legal Center. 2 After recognizing the flawed focus of the 
Law and Development movement of the $60 \mathrm{~s}$ and 70 s, this report called for a more realistic view of the role of law, emphasizing the need to go beyond formal rules to determine who has access to legal processes and how decisions are actually made. The report also emphasized the need for socio-legal research that goes beyond the premise that law plays a positive role but rather recognizes that it can distort or even be an obstacle to development, while hiding behind the facade of change and legal equality (McAuslan, 1997:26.) After all, [...] it is seldom the rules of law that are truly significant or interesting about a foreign legal system; it is the social and intellectual climate, the institutional structures, and the procedures characteristic of the legal system that are instructive» (Merryman, et al., 1994: p.viii) While almost platitudes for contemporary scholars, these concepts nevertheless are often ignored even as given lip service in current law reform aid packages.

It has become common place to emphasize that «Disjointed efforts to judicial reform cannot succeed unless they are linked to measures addressing the deeply rooted political, technical, and structural factors which inhibit effective functioning of the judiciary». Reform is not neutral -it will produce conflicts between "winners" and "losers" (Pinheiro 1999:12.) How can these problems be addressed? Among the practical courses of action future law reform programs could adopt is to ensure the full involvement of local actors, including not just government officials and representatives of opposition parties, but also representatives of indigenous groups and grass root organizations as well as experienced sociologists, political scientists, legal scholars, members of the bar, and other relevant individuals or groups. This participation is essential for pre-implementation studies, as well as follow-up studies or continuing assessments of the projects in question. Moreover, it also is necessary for maintaining the principle that the choice and direction of legal reform, a political decision, rests with each country and not with the agency disbursing the loans and providing external advisors (Faúndez, 1997:3).

There also is a distinct need to foster closer links between the academic and practitioner community through periodic workshops involving both communities. Collaboration of academic and donor and other relevant institutions is needed for creating and organizing non-degree training programs and teaching materials on aspects of law and development. More than one scholar has pointed out the need for 
a renewed focus on comparative studies on the law and the process of reform in both developed and developing countries, including the study of how indigenous institutions evolve and adapt to modern functions (McAuslan, 1997: 34; 43).

In any case, both global and national actors involved in processes of law reform should not dismiss the too often ignored lessons from the past. Not least among these is that all reforms are political. Global inputs and technical expertise by themselves are not sufficient; national support from key constituencies is crucial. Moreover, while foreign institutions should be considered, they must be relevant to local contexts. Finally, reform actors should be prepared for long and unpredictable journeys. There are no quick and easy fixes to long-standing social problems (Id., 37).

\section{References}

SRi RaM Aiyer

1995 "Foreword", in Malcolm Rowat, Malik, W.H., and Dakolias, M., eds., Judicial Reform in Latin America and the Caribbean, Proceedings of a World Bank Conference, Technical Paper No.3 (The World Bank, Washington D.C.).

Centro de Estudios Jurídicos de Uruguay (CEJU)

1993 Interview, Supervisory Commission, Montevideo, Uruguay. September 21. (Notes on file with author).

Jorge Correa Sutil

1993 The Judiciary and the Political System in Chile, in Erwin P. Stotzky, ed., Transition to Democracy in Latin America: The Role of the Judiciary (Boulder, Colo., Westview, pp. 89-106).

Jorge Correa S. y Luis Barros L., editores,

1993 Justicia y Marginalidad; Percepción de los pobres, Santiago, (Corporación de Promoción Universitaria y Dirección de Estudios Sociológicos de la Universidad Católica de Chile). 
Oscar CORREAS

1986 "La Democracia y las Tareas de los Abogados en América Latina", in Joaquim Falcao, de Trazegnies, et al.., Los Abogados y la Democracia en América Latina, ILSA, Ecuador, 207.

Maria DAKOLIAS,

1995 A Strategy for Judicial Reform, 36 Va. Journal of International Law 167.

Maria DAKOLIAS

1999 Court Performance Around the World: A Comparative Perspective, 2 Yale Human Rights \& Development L.J. $87-142$.

Rodrigo DE LA BARRA Cousiño

1998 Legal Reform in Latin America: Legal and Market Relations in Context, Paper presented at ASIL Proceedings of the 92nd Annual Meeting, Washington D.C. On file with author.

Marcus FARO DE CASTRO

1997 The Courts, law, and democracy in Brazil, International Social Science Journal, UNESCO, Blakewell Press, Oxford, June.

Yves DeZalay and Bryant GaRTH

1998 Argentina: Law at the Periphery and Law in Dependencies: Political and Economic Crises and the Instrumentalization and Fragmentation of Law, ABF Working Paper \#9708, American Bar Foundation, Chicago.

Jack DONELLY

1999 Human Rights, Democracy, and Development, 21 Human Rights Quarterly, 608-632.

José Eduardo Faria

1990 El poder judicial frente a los conflictos colectivos, El Otro Derecho, ILSA (Bogotá), No.5. Marzo 1990, pp. 5-34. 
Julio FAUNDEZ

1997 Legal Technical Assistance, in Faundez, ed., Good Government and Law: Legal and Institutional Reform in Developing Countries, St. Martin's Press, New York.

Yash GAI

1993 Constitutions and Governance in Africa: A prolegomenon, in Sammy Adelman and A. Paliwala, Law and Crisis in the Third World, Hans Zell Publishers, New Jersey, pp. 5175 .

James GARDNER

1980 Legal Imperialism, Univ. Of Wisconsin, Madison.

Armando Guevara and Joseph R. Thome

1992 "Notes on Legal Pluralism," Beyond Law, ILSA, Bogotá, No. 5, July, 75-104.

Felipe GonZalez and Felipe VIVERos, eds.

1999 Defensa Juridica del Interes Publico, Cuadernos de Analisis Juridico, Universidad Diego Portales, Santiago.

Linn Hammergren

1998 The Politics of Justice and Justice Reform in Latin America: The Peruvian Experience in Comparative Perspective, (Westview Press, Boulder.)

InTERNATIONAL LEgal CENTER

1974 Research Advisory Committee on Law and Development, Law and Development: The Future of Law and Development Research (Uppsala: ILC and the Scandinavian Institute of African Studies).

Edmundo JarQuin and Fernando Carrillo, eds.

1998 Justice Delayed: Judicial Reform in Latin America, InterAmerican Development Bank, Johns Hopkins University Press, Washington D.C.. 


\section{LATIN AMERICAN WeEkLy RePORT}

2000 New tally of FDI inflows to region, 8 February, London, p.63.

Lawyers Committee for Human Rights and Venezuelan

1996 Program for Human Rights Education and Action, Halfway to Reform: The World Bank And The Venezuelan Justice System, Lawyers Committee for Human Rights and Venezuelan Program for Human Rights Education and Action, New York.

Judge Ana LoREnzo

1993 Trial judge at Civil Court No. 8, Montevideo, Uruguay; Observation of Preliminary Hearing and linterview, Judge Lorenzo and three other judges, Montevideo, September 24, 1993 (notes on file with author)

Dennis LYNCH

1978 Lawyers in Colombia: Perspectives on the Organization and Allocation of Legal Services, 13 Texas International Law Journal, 199.

Julio Maier, Luis Torello et al.

1993 Reformas Procesales en America Latina: la oralidad en los procesos, Santiago, Corporación de Promoción Universitaria.

Patrick MCAuslan,

1997 Law, Governance And The Development Of The Market: Practical Problems And Possible Solutions, in Julio Faundez, ed., Good Government and Law (Macmillan Press, London, and St. Martin's Press, New York).

John Henry Merryman

1977 Comparative Law and Social Change: On the Origins, Style, Decline \& Revival of the Law and Development Movement, 25 The American Journal of Comparative Law 457. 
Matt MofFETT

2000 "Latin America Supplants Asia on Direct Invstment", Wall Street Journal, Feb. 22, pp. A-21 to A-24.

MerRyman, John Henry

1985 The Civil Law Tradition, 2d. Edition, Stanford University Press, Stanford.

Merryman, John Henry, Davis S. Clark and John O. Haley

1994 The Civil Law Tradition: Europe, Latin America, East Asia, The Michie Co., Chalotssville.

Luis Moreno Ocampo, with the collaboration of Roberto DE Michele 1993 En Defensa Propia: Cómo salir de la corrupción, Editorial Sudamericana, Buenos Aires.

THE New YoRk Times

2000 U.N. Trade Meeting Brings Nations Rich and Poor No Closer, 02/ 20/, p. 10.

Rogelio Perez Perdomo

1993 Justice in the Times of Globalization: Challenges and Perspectives for Change in the Administration of Justice in Latin America, Justice and Development in Latin America and the Caribbean (The Inter-American Development Bank, Washington D.C.

Paulo Segio Pinheiro

1999 The Rule of Law and the Underprivileged in Latin America: Introduction, in Juan Mendez, Guillermo O'Donell and Paulo Sergio Pinheiro, The (Un)Rule of Law and the Underprivileged in Latin America, Notre Dame Press, South Bend.

Cristian Riego

1997 The Chilean Criminal Procedure Reform, thesis submitted in partial fulfillment of the requirements for the degree of Master of Laws -LL.M -at the University of Wisconsin Law School. (On file at the UW Law School) 
Andres Rigo SurEDA

1999 Legal and Judicial Reform: Lessons of Experience and the Bank's Future Role, in Andres Rigo Sureda and Waleed Haider Malik, eds., Judicial Challenges in the New Millenium: Proceedings of the Second Ibero-American Summit of Supreme Courts and Tribunals of Justice, World Bank Technical Paper no. 450, The World Bank, Washington, D.C.

Andres Rigo Surfda and Waleed Haider Malik, eds.

1999 Judicial Challenges in the New Millenium: Proceedings of the Second Ibero-American Summit of Supreme Courts and Tribunals of Justice, World Bank Technical Paper no. 450, The World Bank, Washington, D.C.

Felipe SAEZ

1998 The Nature of Judicial Reform in Latin America and Some Strategic Considerations, 13 American University International Law Review 1267.

Saskia Sassen

1999 Globalization, Lecture, Department of Sociology, University of Wisconsin, October 4. (Author's notes, on file).

Boaventura DE SOUSA SANTOS

1995 Toward a New Common Sense: Law, Science and Politics in the Paradigmatic Transition, Routledge, New York, 1995.

1997 Globalization, Law and Democracy Seminar, University of Wisconsin Law School, Madison, Fall, 1997 (Author's class notes, on file).

LA TERCERA

2000 Reportajes, Andres Velasco remueva la Concertacion, Santiago, Chile, February 27, 2000, p. 6 (www.tercera.com/ diario/02/27). 
Joseph R. Thome

1998 Searching for Democracy: the Rule of Law and the Process of Legal Reform in Latin America, Paper presented at the Workshop on Reforma Judicial, Motivaciones, Proyectos, Caminos Recorridos, Caminos por Recorrer, Instituto Internacional de Sociologia Juridica, 6 y 7 de abril, Onati, Gipuzkoa, Spain (on file with author; also available at http:/ /darkwing.uoregon.edu/-caguirre/lawandsociety.htm.)

David Trubek

1974 Law and Development: Then and Now, ASIL Proceedings of the 90th Annual Meeting, Washington D.C., March 27-30, 1996, pp.223-226 David Trubek and Marc Galanter, Scholars in Self-Estrangement: Some Reflections on the Crisis in Law and Development, 1974 Wisconsin Law Review 1062.

UNDP

1997 Governance for Sustainable Human Development, UNDP Policy Document, United Nations Development Programme, January (http://magnet.undp.org/policy/ default.htm)

Esteban Valenzuela

1999 Modernity: an Endless Goal in Chile- Two old and one new item on the Chilean agenda for the year 2000: poverty, democratization and political cultural reform, Directed Research Paper, Summer 1997 (on file with author). Vienna Declaration and Programme of Action, U.N. GAOR, World Conf. On Hum. Rts., 48th session, 22nd plen. Mtg., part 1 par 8, U.N. Doc. CONF.157 (1993), as cited in Donelly.

William C. WHITFORD

2000 The Rule of Law, Madison, Draft of July 6, 1999, forthcoming in Univ. of Wisconsin Law Review, Fall. Ms. on file with author. 
The World Bank

1999 Press Conference: World Development Report 1999/2000 "Entering the 21st Century", The World Bank, Washington, D.C., Sept. 15 (on file with author).

The World Bank

1999 Press Backgrounders, Development, Human Rights, and Judicial Reform, The World Bank, December, (www.worldbank.org/html/extdr/pb/pbhr.htm).

The World Bank

1999 News Release No. 2000/141/LAC, World Bank Launches

Paper on Justice and Indigenous Peoples in Latin America, The World Bank, Dec. 9, (www.worldbank.org/html/extdr/ extme/141.htm). 